\title{
Aboriginal linguistic exchange in an Australian city
}

\author{
John Mansfield, University of Melbourne
}

Revised October 2021, to appear in The International Journal of the Sociology of Language

\begin{abstract}
Tropical northern Australia is a region of high linguistic diversity, with dozens of language varieties each spoken by a small number of people. Traditionally, this level of diversity has been supported by egalitarian linguistic ecologies, where Aboriginal people use multiple languages alongside one another in each local region. In this study, I explore new types of multilingual practices that are emerging in Darwin, the only major city in the area. Aboriginal people from the homelands often visit Darwin, and some become permanent residents, which provides the context for new types of multilingual encounters. Kriol and English are also used as a 'fall-back' languages to mitigate gaps in understanding, which allows multilingual interaction to occur between people who have only partial knowledge of each others' languages. I characterise these practices as 'linguistic exchange', used by speakers to establish their links to kin and country, while also showing respect for their interlocutor's social connections. Linguistic exchange also supports the distinctive Aboriginal mode of demand-driven resource sharing. Aboriginal language use in Darwin suggests that urban mobility is not necessarily detrimental to the future vitality of the region's rich linguistic heritage.
\end{abstract}

\section{Keywords}

multilingualism, Australian languages, urbanisation, language maintenance

\section{Acknowledgements}

This article is indebted to Aboriginal homelands people in Darwin who shared their language practices with me. Erica Bangun, Steven Burrunjuck, Margaret Dulla, Chrissie Tchemjiri, and Jeremiah Tunmuck were especially generous in teaching me about Darwin life and language. This study was also greatly facilitated by $\uparrow$ Cathy Bow, whose insights and kindness were a highlight of my stays in Darwin. I like to think that Cathy would have enjoyed reading this article. Funding for this research was provided by the Australian Research Council, grant number DE180100872. 


\section{Introduction}

European invasion and colonisation of tropical northern Australia began in in the late nineteenth century, but over a century later, the region still has the feel of a colonial frontier. There is one major city, Darwin (pop. 137,000), home to thousands of Australian settlers who originate from Europe, South-east Asia and elsewhere, as well as a minority Aboriginal population. But beyond Darwin, settlements on the various Aboriginal homelands are much smaller, and for the most part have only a few nonAboriginal residents. The region is geographically vast and sparsely populated, and most of the homeland settlements are far from Darwin. Geographic distance is reflected in cultural and linguistic distance: while English is dominant in Darwin, in homeland settlements most people speak either traditional Aboriginal languages, or Kriol (the regional English-lexified creole).

In this context, Aboriginal people from the homelands are cast as cultural and linguistic outsiders in the urban centre. They are outsiders with respect to the dominant, English-language settler culture of Darwin. But on the other hand, homelands Aboriginal people have their own networks and practices in Darwin, where standardised Australian English has no status, and mainstream social institutions are kept at arm's length. For example, many homelands Aboriginal people in do not live in mainstream housing (see details below). Within this network, visitors from the homelands accrue social capital by developing connections with visitors from other homelands, using Aboriginal languages as a means of realising these connections.

The use of Aboriginal languages in Australian cities has so far received little attention in the linguistic or sociolinguistic literature, though there is recent research on Aboriginal English in Perth (Rodríguez Louro \& Collard 2021). The current study is the first dedicated account of homelands ('traditional') languages being used in a major city. I focus in particular on speakers of Murrinhpatha, a sociolinguistically vibrant Aboriginal language, describing patterns of language use I have observed when spending time with Murrinhpatha speakers in Darwin. However, many of the encounters I observed were multilingual encounters involving speakers of Anindilyakwa, Burarra, Tiwi, Wadjiginy and Yolnu Matha. In these encounters, speakers draw upon languages as currencies for cultural exchange (Bourdieu 1977; Irvine 1989), although they also often use Kriol or English as a lingua franca. I observed these forms of linguistic exchange both among short-term visitors to Darwin, as well as long-term residents, and even Aboriginal people who have grown up and lived most of their lives in Darwin.

Urban linguistic exchange is a key element in the evolving sociolinguistic landscape of Aboriginal Australia. As I will argue in this article, urban linguistic exchange connects Aboriginal pasts with futures: mobility and exchange have rich traditions in Aboriginal Australia, but the urban context radically alters the social and political fabric of these practices, and enlarges the scale of multicultural connections to encompass the whole of northern Australia and beyond.

The remainder of this article runs as follows. In section $§ 2$ I provide some background on Aboriginal mobility between homelands and the city of Darwin, 
highlighting the lack of sociolinguistic research in this area. In section $\S 3$ I provide sociolinguistic background on Aboriginal multilingualism in general, and the Murrinhpatha language in particular. Sections $\S 4$ and $\S 5$ provide the main original contribution of this article, describing language practices of Murrinhpatha and other Aboriginal people in Darwin, focusing firstly on short-term visitors, and then on longterm residents. Section $\S 6$ reflects on how these practices continue Aboriginal traditions of mobility and cultural exchange, but reshape and rescale them in the context of a major urban centre.

\section{Homelands Aboriginal people in Darwin}

When Darwin was founded on the northern Australian coast in the second half of the nineteenth century, it was intended to be a colonial outpost for European settlers (Powell 1982). The Aboriginal populations of the region were expected to remain in their homelands, and to settle the Christian missions or government ration stations established on those lands. In the early twentieth century, the Larrakia people who owned the Darwin region were confined to a compound in the town, while Aboriginal people from other homelands were discouraged from entering the town at all, and sometimes forcibly removed (Povinelli 1994; Wells 2000). When Aboriginal people did visit Darwin, this was typically characterised as 'drifting', with an emphasis on the attractions of alcohol, opium and other urban vices (Benn 1994: 79; Day 2001: 41). During the second world war, homelands Aboriginal people who had been living in Darwin or on cattle stations were forced into army camps (Berndt \& Berndt 1987), creating an intensity of multiethnic mixing that is a precursor to the situation today in Darwin.

The negative characterisation of homelands Aboriginal people visiting Darwin remains dominant in popular media and in Darwin local politics. Aboriginal visitors are seen as a problem, a threat to the social order of the town and a danger to themselves, especially due to heavy drinking (see Figure 1). On the other hand, the Aboriginal activist Noel Pearson has proposed an alternative vision for these visitors. Pearson has promoted the concept of 'orbiting' between homelands and the city, whereby Aboriginal people can access employment and educational opportunities while maintaining connections with their traditional lands (Pearson 2000; for a critique see Neale 2019). This is a strikingly different metaphor for mobility, suggesting a benificent cyclic movement in place of the one-way drift to destitution. Some of the homelands Aboriginal people I met during this study do indeed see Darwin as a place of employment and educational opportunities, but in this article I focus on another kind of opportunity. Darwin is a central node for the development of new social networks, often connecting Aboriginal people from distant homelands. Orbiting to Darwin therefore offers a form of social capital, alongside the potential economic benefits highlighted by Pearson (see also Coulehan \& Gaykamanu 2013). I return to the nexus of mobility, social capital and multilingualism in the next section (§3). 
(a)
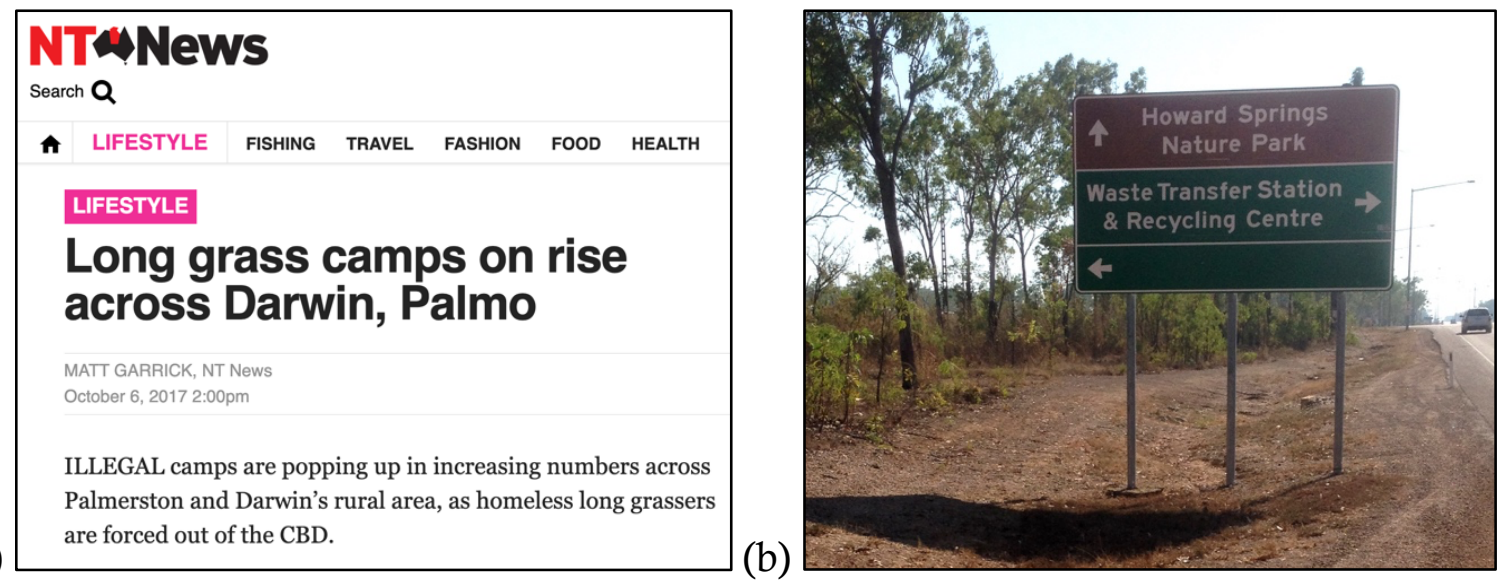

Figure 1. (a) A headline from the NT News, online edition, 6 October 2017. 'Long grass camps' are the open-air camps of homelands Aboriginal people, and 'Palmo' is Darwin's twin city, Palmerston. (b)

The bottom section of this road-sign, on the outstkirts of Darwin, points towards a 'town camp' where homelands Aboriginal people live - but the sign is curiously blank.

There are several ethnographic studies of homelands Aboriginal experiences in Darwin. Sansom (1980) describes people from the Daly River region who set up an informal camp by the highway leading into Darwin in the 1970s, with a focus on how this group order their economy and group politics, largely separate from the adjacent settler society. Day (2001) describes Burarra people who establish a camp in bushland near the city, and develop an oppositional politics in response to their marginalisation from social services. There are also studies of similar situations in Katherine, a smaller city to the south-east of Darwin (Merlan 1998), and Alice Springs, the major city in central Australia (Collman 1988; Burke 2018). Burke's study is of Warlpiri people who have migrated to various cities, especially women who adapt Warlpiri ways of being to urban contexts. Burke mentions recontextualisations such as traditional food-gathering practices around the city of Alice Springs, and establishment of a traditional widows' camp with assistance from an urban Christian congregation. He also describes the extensions of personal freedom and development of relationships that go beyond the traditional Warlpiri kin network. This is similar to the new social networks reported on in this article.

The ethnographic studies include some general commentaries on language use, though none offers detailed, explicit descriptions of usage patters. Sansom $(1980: 25,38)$ highlights the role of language in social exchange at the highway camp, noting that individuals and groups have exclusive rights to particular turns of phrase. It is implied that these exchanges involve forms of Kriol, though he does not give examples. Sansom (1980: 11, 28, 32) also notes that the camp group speak a range of languages from their homelands, but although some are multilingual, he reports that use of these languages is barely tolerated in the camp, with Kriol instead preferred for group interaction. He claims that Kriol ('that Darwin style') is used in the camp to create a shared group identity. This appears to conflict somewhat with brief observations by Brandl and Walsh 
(1982), who report that multilingual usage is valued if not expected in Darwin. As we will see below, my own observations accord with the latter view.

Some other studies mention language within homeland groups in Darwin. Day (2001: 13) identifies use of the Burarra language as one among several practices (also going barefoot, and cooking on open fires), which set this group apart from nonAboriginal Darwin society. Yolyu residents of Darwin also continue to use their own language, and maintain continuous contact with their Yolyu homelands kin (Coulehan 1995: 185). Burke (2018: 117) observes that second-generation Warlpiri migrants in Alice Springs have somewhat uneven knowledge of the Warlpiri language, which creates paradoxes with respect to Warlpiri identity.

In this article I provide a more detailed description of language use by homelands Aboriginal people in Darwin. My focus is on speakers of Murrinhpatha, for whom English is a second language and in some cases not one in which they are comfortable communicating. Language therefore contributes to their sense of otherness in the city. But Murrinhpatha speech also produces solidarity among the group in an often hostile urban terrrain. Language also opens up new experiences for Murrinhpatha people in Darwin. Connections to distant social networks are developed through linguistic exchange, and this accrues social capital to the speakers.

\section{Aboriginal multilingualism, linguistic exchange and Murrinhpatha}

Evidence suggests that multilingualism was the norm in Australia before European invasion (Sutton 1978; Wilkins \& Nash 2008; Singer \& Harris 2016; Evans 2018), though multilingual practices have been greatly reduced since then. In much of the country, Aboriginal people were pressured to shift to English, though many local communities are now in the process of reawakening their languages. In the arid centre and the tropical north, Aboriginal languages have maintained unbroken transmission, but even here there has been a tendency in each region for multiple local languages to be replaced by a single language that has dominance where the main settlement was established (Mansfield 2022).

There are a few places in Australia where multilingualism or multidialectalism has been maintained, such as Maningrida (Elwell 1982; Vaughan 2021) and Warruwi (Singer \& Harris 2016). In these two towns there are high levels of individual multilingualism, i.e. most individuals can speak and/or understand several languages. An important communicative practice that helps to maintain this is RECEPTIVE MULTILINGUALISM, where interlocutors each speak in their own preferred language, rather than converging on a common language. Receptive multilingualism provides a counter-example to interactional accommodation, i.e. interlocutors converging on a common code, which is sometimes presented as a universal of human linguistic interaction (Giles \& Ogay 2007). Interactional practices in Indigenous settings such as Australia and the Amazon suggest that on the contrary, accommodation is a culturally specific convention (Lüpke 2016). Sign language is another means of communication 
between groups, though it is less linked to group identity (Green 2022), and in the current study I did not observe distinctive signing practices.

In this article I focus on Murrinhpatha speakers in Darwin, though I also mention several other languages. I highlight multilingual practices in the city, which include not just receptive multilingualism, but also respectful use of others' languages. I characterise these encounters as LINGUISTIC EXCHANGE, following previous work that highlights the use of languages as socially valued mediums of exchange (Bourdieu 1977; Irvine 1989). Linguistic exchange is used by speakers to establish their positions and relations in social networks, while also showing respect for their interlocutor's social network position. Networks of kin are considered to be inseparable from areas of country, and country is the basis for spirituality and wellbeing. Therefore language simultaneously indexes kinship, country and spirituality. In this context, respectful use of another's language becomes a powerful technique for softening demands, i.e. 'positive facework' in the terms of Brown and Levinson (1987), and this is especially important in the demanddriven mode of Aboriginal resource sharing (Peterson 1993; Peterson 2013).

I mentioned above that Australian Aboriginal people may use orbiting as a way of developing social capital, as opposed to the 'career capital' that is implied in Pearson's (2000) work. Social capital involves the development of social networks in which individuals are valued by virtue of their standing and connections. This 'relational selfhood', built and maintained via social networks, has been argued to be key to Australian Aboriginal peoples' sense of spiritual and emotional well-being (Myers 1979; Myers 1986; Austin-Broos 2009; Glaskin 2012). Language has a major role in this type of self-development, as linguistic skills are one way of establishing or testing individuals' connections to social networks. Bourdieu's (1977; 1991) work on language as 'symbolic capital' focuses on stratified prestige in urban capitalist society, but a very different perspective is offered by Irvine (1989), who describes how Wolof griots build their reputations by demonstrating verbal skills. Irvine notes that:

'verbal skills and performances are among the resources and activities forming a socioeconomic system; and the relevant knowledge, talents and use-rights are not evenly, randomly, or fortuitously distributed in a community' (Irvine 1989: 11)

Irvine's comment about the non-random distribution of verbal skills is particularly relevant to Australian Aboriginal linguistic exchange, where social capital is attained not by the absolute breadth of one's linguistic repertoire, but by its appropriateness to one's clan heritage and other social connections. As we will see below, multilingual exchange also has an important role in the exchange of material resources or more generally rendering help (Sansom 1988; Merlan 1991).

An economy of linguistic exchange can also be seen in multilingual practices of the Lower Fungom region of Cameroon (Di Carlo 2018). Each village in Lower Fungom has its own local language, and an individual whose kinship network links to several villages may index those relationships by use of multiple languages. Being able to speak multiple languages broadens one's range of social and spiritual support, a 
'diversification of investments' in the social network (Di Carlo 2018: 157). Lower Fungom multilingualism is now threatened by an encroaching lingua franca, and as mentioned above this is also the case in northern Australia, where Kriol/English is now an option for communication between people from different language groups. However, as shown in this study, multilingual exchange still persists even in the regional capital of Darwin. Murrinhpatha plays a vibrant role in these exchanges in Darwin, alongside other languages such as Anindilyakwa, Burarra and Yolyu varieties. In general, the use of Aboriginal languages in Darwin reflects their level of use in homelands communities: Murrinhpatha is the dominant language in the towns of Wadeye and Nganmarriyanga; the other languages just mentioned are similarly dominant in their own homelands settlements.

Murrinhpatha has about 3000 speakers, most of whom are concentrated in Wadeye and Nganmarriyanga. These towns are about five hours' drive from Darwin, with a substantial portion of the road being unsealed, and often impassable during the monsoonal rains. An alternative mode of transport is offered by light airplanes that travel to and from Wadeye once or twice a day. In contrast to many other Australian Aboriginal languages, the current speaker numbers for Murrinhpatha very likely represent an increase from the pre-colonial era. In 1939 Catholic missionaries established a mission at Wadeye (which they named Port Keats), on the land of the Dimirnirn people, one of several Murrinhpatha-speaking clans (Pye 1972; Ward 1983). The mission soon attracted around 20 clans from the surrounding country, who spoke a range of languages. Only about a third of the people settling the mission were from Murrinhpatha-speaking clans, but Murrinhpatha speakers asserted that their language should be spoken at the mission, due to its location on Dimirnirn land, and a generalised language shift to Murrinhpatha was further encouraged by children of all clans residing together in missionary dormitories (Mansfield 2014: 96-98). Children growing up in Wadeye today learn Murrinhpatha as their first language, while other Aboriginal languages of the region, such as Marri Tjevin and Marri Ngarr, are spoken by only a few, mostly elderly people. Kriol is occasionally used with Aboriginal kin who have grown up outside the region. English is used only for interaction with non-Aboriginal service workers in contexts such as the town shops, the welfare office and clinic.

All the clans who settled Wadeye were traditionally engaged in trade, ceremonial and marriage exchange with each other. We do not know much of pre-missionary language practices in the Wadeye region, though an early ethnographic report states that adults in the region 'usually ... speak two or more' of the local languages (Falkenberg 1962: 13). It seems likely that receptive multilingualism was once the norm in the Wadeye region, though clan politics, language ideology and missionary interventions have led to convergence on Murrinhpatha. The current Murrinhpatha-speaking population continue to identify with their clans and their heritage languages, while also partly embracing the idea of a new, unified identity coalescing around the Murrinhpatha language. 
In the following sections I describe some of the salient social practices of Murrinhpatha speakers in the city of Darwin and especially their linguistic practices. I draw on four months of field research in Darwin between 2018-2020. I am a nonIndigenous researcher, and therefore a stark outsider with respect to the network of homelands Aboriginal people in Darwin. On the other hand, I have worked extensively with Murrinhpatha people in Wadeye and Nganmarriyanga, and it was these preexisting relationships that provided the starting point for my Darwin research. Based on their social connections in Darwin, I gradually got to know more Darwin-based speakers of Murrinhpatha and other Aboriginal languages.

I recorded nine interviews in Darwin, with speakers of Murrinhpatha and other languages. I began theses interviews by asking about language use and kin connections in the city, though in most cases the discussion soon moved onto other topics, often not directly related to language. The kin/language connections reported in these interviews might provide a quantitative snapshot of Aboriginal language connections in Darwin, though in this study I focus on qualitative aspects of the data. I also learnt much about Aboriginal language use in Darwin through participant observation, either when working with Murrinhpatha people on other language-related projects in the city, or in the course of day-to-day activities such as shopping, eating and visiting the beach. The information about language use in this article therefore consists of a mixture of selfreporting (especially from the interviews) and direct observation (especially from participant observation). With regards to self-reported language use, I have the impression that homelands Aboriginal people in Darwin tend to understate their knowledge of languages, rather than overstate. The exceptions to this are when someone's paternal language is no longer widely spoken, but they may nonetheless be said to 'speak the language' in the sense of having an ancestral right to speak it, irrespective of actual usage (Evans 2007).

Beyond general information about which language is used when, further insights could be attained by recording naturalistic Darwin conversations, in which multiple languages are used (as done by Singer and Harris 2016 in Warruwi). However this will not be done in the current article, largely due to methodological constraints. I have been able to informally observe multilingual interaction in Darwin on many occasions, and some of the details provided below are based on notes take during or immediately after such interactions. ${ }^{1}$ However I have not been able to make any substantial audiorecordings of multilingual interactions, due to the nature of their occurrence. The multilingual interactions I observed were always spontaneous, rather than planned as part of my research; interlocuors arrived and departed, and there was usually at least one party not familiar to me. Such situations are not conducive to ethical recording of audio materials, though further Darwin fieldwork may eventually present opportunities for such recordings.

\footnotetext{
${ }^{1}$ I have basic communicative competence in Murrinhpatha, and I have learnt a few useful expressions in other Aboriginal languages during my time in Darwin.
} 


\section{Taking a break in Darwin}

Murrinhpatha speakers visit Darwin for a wide range of reasons, but one common motivation is a break from everyday life in Wadeye. Darwin is one of the most popular 'holiday destinations' for Murrinhpatha speakers. A break in Darwin is motivated both by the desire to escape the pressures of everyday life in Wadeye, and the desire for a range of experiences that the city has to offer. Life in homeland settlements is characterised by a network of kin relationships that must be constantly negotiated and maintained, especially via demands for assistance and sharing of resources (Peterson 1993; Austin-Broos 2009: 133ff.; Burke 2018). This can make the settlements a stressful place, especially for more senior people who command more resources, and therefore must negotiate between more demands. In Darwin people experience fewer demands, and have an opportunity to use their time and resources for their own enjoyment. There are also instances where protracted stays in Darwin may be used to escape deeper conflicts on homelands communities (Maypilama et al. 2004).

A break in Darwin can thus be a liberation from everyday responsibilities. Murrinhpatha speakers recognise that Darwin is the land of the Larrakia (see also Fisher 2012; Fisher 2013), but the vast majority of people they encounter on their visits are nonLarrakia, and therefore they do not experience the same types of cultural and linguistic responsibilities to their hosts that they have when visiting other homelands. This may contribute to Murrinhpatha speakers feeling less constrained about using their own language in Darwin, compared to if they visited, say, the town of Gunbalanya in the Kunwinjku homelands.

Murrinhpatha speakers visiting Darwin usually prefer to stay at the houses of kin who live in Darwin, and these kin usually speak Murrinhpatha or other Aboriginal languages. Below I return to the question of interaction between short-term visitors and long-term residents. If accommodation with kin is not available, some visitors stay at commercial hotels or non-profit hostels near the airport, but often they camp in parks aound the city's northern suburbs (Day 2001; Holmes 2007; Holmes \& McRae-Williams 2008; Kowal 2015 ch.3). Murrinhpatha speakers have their own characteristic camping areas around Darwin, and other groups such as Burarra and Yolngu speakers likewise have recognised regular spots (Day 2001; Kowal 2015: 69). This camping practice is generally known in the region as 'long-grassing' (in Murrinhpatha, langkrath), following an earlier era when homelands Aboriginal people visiting Darwin concealed their camps amongst shoulder-high speargrass to avoid being evicted by police (Day 2006). Longgrass camping does not conform to standard expectations of an urban experience, since it involves staying in natural environments on the periphery of the built environment. Long-grass campers bring some bush traditions to the city, including food gathering practices. One popular Murrinhpatha campsite in Darwin has a well-known food gathering site nearby for the edible mollusc $k u$ thali; another site is known for easy hunting of ku walet 'fruit-bats', and the group who habitually camp at this site are 
sometimes referred to as $k u$ walet mup 'fruit-bat people'. Long-grassers also sometimes burn off the accumulated dry grass around their camps in dry season, much as they would back on their own country. A Murrinhpatha speaker characterised this as 'helping out' the Larrakia owners.

Nonetheless, traditional food collection in Darwin is more of a practical facility, rather than a major attraction of the city. Indeed, being able to shop for a wider range of goods than what is available on the homelands is one of the key attractions. Casuarina Square, a large indoor shopping centre in Darwin's nothern suburbs, is one of the main sites of urban convergence for homelands people from across northern Australia. Five or more Aboriginal languages can be heard on a walk through the mall, or at the bus terminus outside. Murrinhpatha visitors often go to Casuarina as one of their first stops on arrival, seeking more varied and affordable clothing that what is available in Wadeye.

Another attraction of Darwin, at least for some Murrinhpatha visitors, is the availability of alcohol. 'Drunk Aboriginal people' has been widely used as a racist trope in popular discourse (Day 2001: 50; Holmes \& McRae-Williams 2008; Fisher 2012; Carson et al. 2013). ${ }^{2}$ On the other hand, Murrinhpatha speakers themselves often voice damning views of Darwin drinking. Riding in a Darwin taxi with a senior Murrinhpatha woman, she gazed out at Murrinhpatha long-grassers and stated bluntly (in English), 'They shouldn't be here.' Drinkers sometimes sleep without shelter or protection, and this makes them vulnerable to violence, robbery or arrest. Habitual, addictive drinking is seen as causing personal decline or ngepan derrenganputh, 'wasting one's spirit'. But Murrinhpatha people also see the positive side of Darwin drinking, as part of a scene of heightened sociality, camaraderie, and an opportunity to forget the stresses of home (Merlan 1998: 206).

Gatherings at Casuarina shopping centre, or drinking parties in nearby parks, are key sites of linguistic exchange for Murrinhpatha and other homelands Aboriginal people. Murrinhpatha visitors to Darwin constantly encounter Aboriginal language speakers from other homelands, and wherever a shared connection can be established, this provides an opportunity for multilingual interaction. This type of interaction is most intensive in the heightened sociality of the aforementioned drinking parties. For example, one group I chatted with near a beach consisted of around a dozen men and women: three Murrinhpatha speakers; a few Burarra speakers from Maningrida; a couple of Djambarrpuynu (Yolyu Matha) speakers from Milingimbi; and one man who said his languages were both Warlpiri and Pitjantjatjara. The Murrinhpatha and Djambarrpuyyu speakers were related by marriage. The map in Figure 2 shows the homelands of these languages. The group were freely sharing their supply of kura sadni

\footnotetext{
2 The racist tropes overlook the fact that homelands Aboriginal people actually consume far less alcohol than non-Aboriginal Darwinians. For example, alcohol is essentially banned on the Murrinhpatha homelands. Although some alcohol is available with restrictions in the towns of Peppimenarti and Nauiyu, Darwin is the main destination for Murrinhpatha people when they want to drink freely. The illusion of 'Aboriginal drunkenness' is thus created by the fact that people from Wadeye and other homelands can only drink freely if they go to Darwin.
} 
'boxed white wine' ( < chardonnay), and freely addressing each other using expressions from their homelands languages, as well as Kriol or (Aboriginal) English. ${ }^{3}$ This is in stark contrast to Samson's report of multilingual groups enforcing a general prohibition on any language that is not known by all.

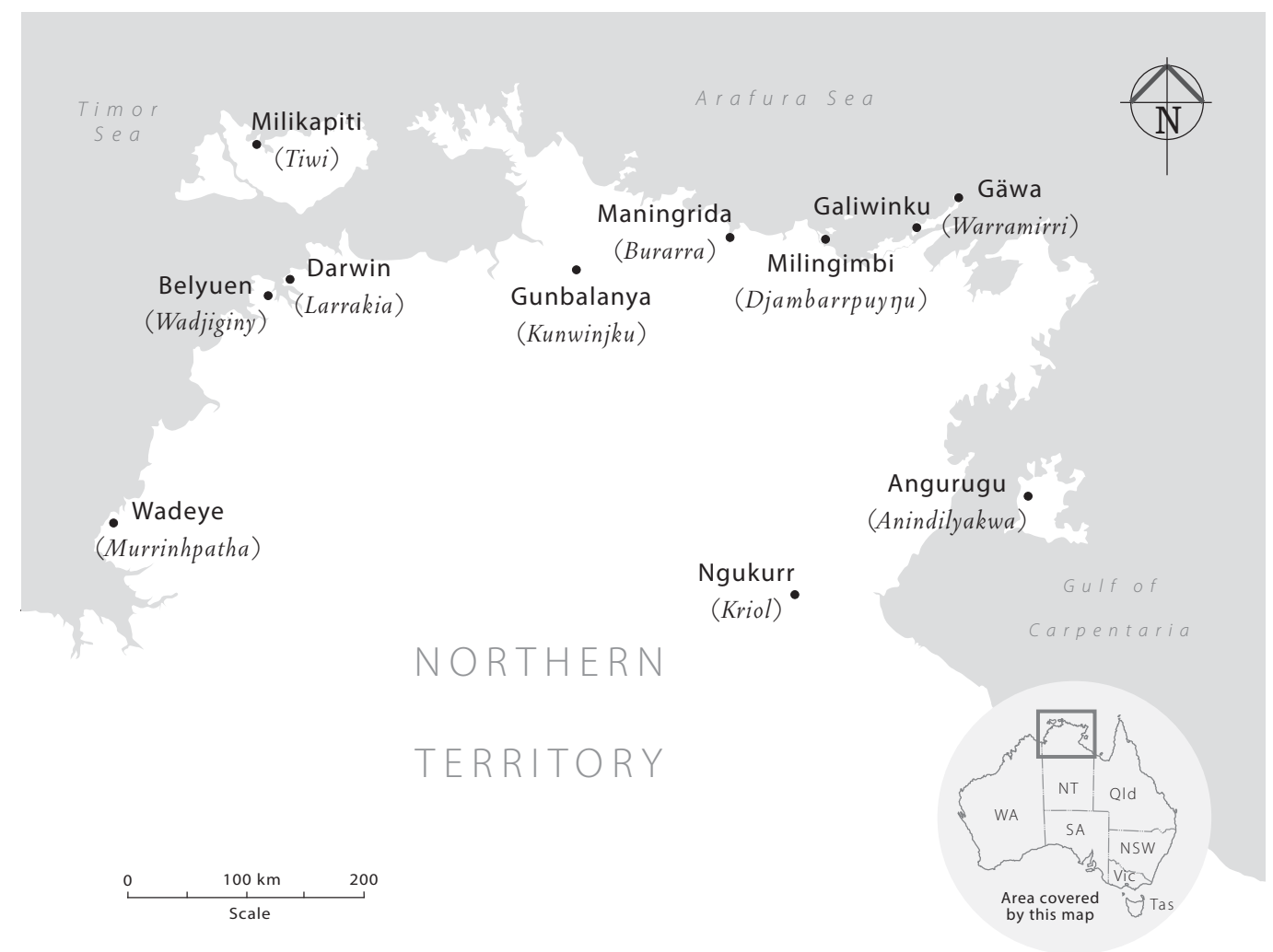

Figure 2. Homelands of the main languages mentioned in this article. Luritja, Pitjantjatjara and Warlpiri are in desert areas to the south.

On another occasion, a drinking group combined Murrinhpatha and Anindilyakwa speakers, both men and women, aged between about 30 and 60 . Though I witnessed several multilingual drinking parties first-hand (including the one outlined above), on this occasion the drinking party was described to me in detail by a Murrinhpatha friend, 'Manh'. He was staying with me in Darwin, and in the evenings would spend time with this countrymen in the park. Knowing that I was interested in multilingual interaction, on one evening he gave me a detailed account of how language was used in the group. The two groups were connected via a Manh's uncle, 'Pathama', who married an Anindilyakwa woman. He thus had Anindilyakwa affinal kin, from whom he had learnt some Anindilyakwa language. Pathama lived mostly in Darwin, and he had met up with visitors from the Murrinhpatha homelands, who were long-grassing near the airport.

\footnotetext{
${ }^{3}$ In Darwin there are speakers of Kriol proper (e.g. those from homelands such as from Belyuen or Ngukurr), but the Aboriginal English used in the region is very similar to Kriol, and there may ultimately be a continuum between the two (Angelo 2022). Without having studied these varieties in detail, I am not able to distinguish between them in this study.
} 
They were also joined by Anindilyakwa long-grassers related to Pathama by marriage. In the drinking group, Pathama sat near an Anindilyakwa affinal relation 'Nakakiruma', as shown approximately in Figure 3. Pathama and Nakakiruma each used their own homeland language to address the other, with Kriol or English available as a fall-back. But Nakakiruma also at one point crossed into Murrinhpatha, making a request to Pathama: nanthi beg ngay nangart 'give me my bag'. This is a relatively sophisticated example of second-language use, with the verb na-nga-art 'hand.2SG.IRR-1SG.DAT-get' demonstrating correct use of a complex verb inflected for subject and dative participants. Other members of each sub-group also sometimes 'crossed' into the other group's language, but only for making simple requests. For example, Manh made requests using the Anindilyakwa words dambakwa 'tobacco' and angwura 'fire, cigarette lighter', while his (indirect) Anindilyakwa kin made requests using the Murrinhpatha word thungku 'fire'. It is notable that all the speech acts in which Manh reported switching are demands.

\section{Anindilyakwa Murrinhpatha}

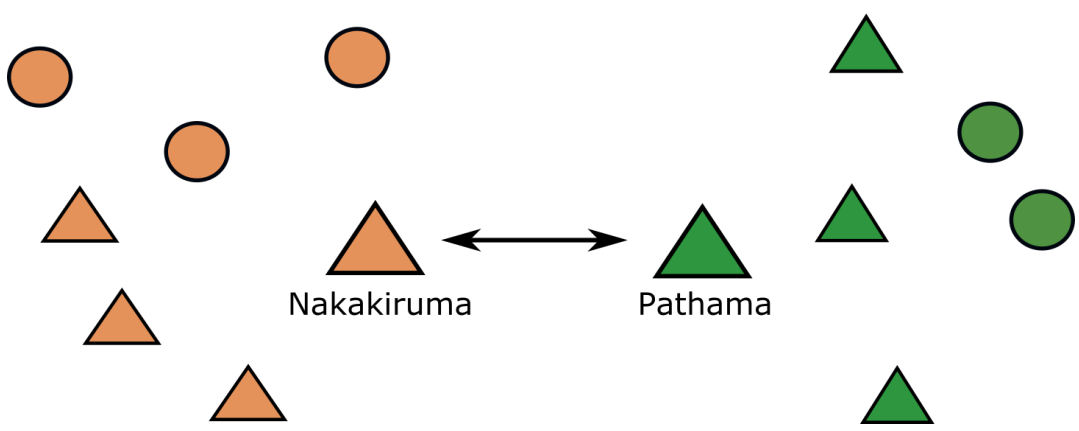

Figure 3. Language exchange in an Anindilyakwam - Murrinhpatha drinking party in Darwin.

The acquisition of basic vocabulary in others' languages is part of a wider pattern of linguistic diplomacy practiced in Darwin. Speakers learn and use words from each others' languages as a means of showing respect. This is most important when formulating requests, e.g. for tobacco, which are a key way of establishing relatedness. ${ }^{4}$ Aboriginal social networks are to a great extent 'demand-driven', with an expectation that resources will be shared in response to demands, rather that waiting for those who have resources to offer them (Peterson 1993; 2013). Sharing is expected, but it is also calibrated to degrees of relatedness. Therefore when one instigates sharing by making a request, this has a dual function of both obtaining resources, and also establishing or reaffirming social relatedness. In the context of Darwin, where homelands Aboriginal people are negotiating relatedness with people from different language groups, switching

\footnotetext{
${ }^{4}$ Laycock (1979: 91; cited in Wray \& Grace 2007: 565) describes how some Papuan people who speak different languages explicitly instruct one another on how to express key requests such as 'tobacco' and 'areca nut'.
} 
into the interlocutor's language is therefore a skillful way of enhancing the social dimension of the request, by highlighting the interlocutor's relations to language and country.

Darwin visitors therefore may command a mini-vocabulary of common basic expressions in languages such as Anindilyakwa, Burarra, Yolngu, and in some cases Murrinhpatha. Although Aboriginal people are very careful not to lay claim to languages over which they do not have a hereditary right, Darwin speakers do show some pride in their learning of diplomatic vocabulary. A Warramirri (Yolngu variety) resident of Darwin explained to me that language learning is important for both respect and communication, and emphasised the patience and listening required for such learning. He also mentioned that he sees such learning as part of Darwin's 'multicultural' identity. This is an interesting formulation, given that Darwin officially promotes itself as multicultural, but this usually refers only to migrant cultures.

Table 1 lists diplomatic vocabulary words that were mentioned to me by longgrassers and some permanent residents. In some instances the speaker had given a negative response when I asked in general if they knew that language, but turned out to know several words when I asked about them specifically.

Table 1. Darwin basic vocabulary for linguistic diplomacy

\begin{tabular}{|c|c|c|c|c|c|}
\hline & ANINDILYAKWA & BURARRA & KUNWINJKU & MURRINHPATHA & YOLNGU \\
\hline tobacco & dambakwa & djambaka & baki & mi-gathu & narili \\
\hline lighter & angwura & bol & & thungku & gurrtha \\
\hline none, nothing & nara & ginyagara & larrk & mami & (yaka) baynu \\
\hline $\begin{array}{l}\text { (alcoholic) drink } \\
\text { good, okay }\end{array}$ & anija & bugula & & kura & $\begin{array}{l}\text { yanitji } \\
\text { manymak }\end{array}$ \\
\hline $\begin{array}{l}\text { come here! } \\
\text { sit down, wait! }\end{array}$ & $\begin{array}{l}\text { guwa! } \\
\text { angbarriya! }\end{array}$ & guwa! & & mup thi! & \\
\hline
\end{tabular}

Unsurprisingly, these small learnings of other languages show some signs of imperfect learning. For example, a Murrinhpatha speaker told me bayigu instead of Yolngu baypu 'none', and damuga instead of Anindilyakwa dambakwa 'tobacco'. Murrinhpatha speakers also show some uncertainty as to whether a term comes from Anindilyakwa, Burarra or Yolngu, presumably related to the fact that a single term, murrinh malarrk 'Arnhem-land language', may be used to designate any of these languages.

Murrinhpatha people may also refer to Yolngu people specifically as yaka baypu mup 'yaka bayyu people', in reference to their term for 'none, nothing' (see Table 1).

The long-grass thus provides a site for linguistic exchange between Aboriginal people whose homelands are far apart. While multilingualism was traditionally the norm in northern Australia, the linguistic exchanges occurring in contemporary Darwin involve new connections between speakers of languages that were not previously in contact. Darwin linguistic exchange may also occur between traditional Aboriginal languages and Kriol, which is now the main language of several homeland settlements. I observed an example of this at Casuarina shopping centre, where I was eating lunch with two Murrinhpatha speakers, who encountered a kinsman from the town of Belyuen, 
where Kriol is the main language. The group conversed for a while, maintaining fairly consistent separate languages: the Belyuen man addressed the Wadeye people in Kriol, and they addressed him in Murrinhpatha. He appeared to comfortably understand Murrinhpatha, including complex verbal expressions such as dem-dharl pirrim '3SG.REFLclose stand = it's closed'. It was later explained to me that the Belyuen man understands Murrinhpatha because he has spent some years there, living with other kin. He identified his main heritage language as Wadjiginy (or the closely related variety Kiyuk), though I did not hear him use any Wadjiginy expressions. However, alongside Kriol, he did use some isolated Murrinhpaha expressions, such as puy-ya! 'keep going!' and pule 'brother'. I suggest that by using these he reinforced his kin connection to Murrinhpatha people, and his interlocutors in turn recognised this connection by addressing him in Murrinhpatha.

The exchange of Aboriginal languages in Darwin also takes place to some extent with non-Aboriginal residents, though interestingly I have only observed this with recent migrants who themselves speak languages other than English. For example, a Chinese shop-owner who regularly provides goods to Murrinhpatha long-grassers has learnt a number of Murrinhpatha swear words, which he rather incongruously enunciates at the end of transactions. I watched him hand over oranges and a loaf of bread, then say Kuthuk! 'Fuck!', much to the joy of his Murrinhpatha customers (cf. Kowal 2015: 78). A Yolyu man remonstrating with an African migrant security guard at Casuarina shopping centre repeatedly addressed him as wäwa 'brother'. Various Yolyu Matha speakers told me that south Asian taxi drivers in Darwin know some of their language. Not quite convinced, I quizzed one driver about this and he immediately mentioned several expressions including nhä-mirri marrtjin 'where are you going?', manymak 'good', ngarali 'tobacco' and bobo 'goodbye'. 5 These Aboriginal-migrant linguistic exchanges presumably reflect the fact that many of the useful exchanges homelands Aboriginal people have in Darwin are with recent migrants, who run the grocery stores, guard the shopping centres, and drive most of the taxis. Alongside money, Aboriginal speakers exchange language in these encounters, in return receiving valued goods and services.

\section{Settling in the city}

While many Murrinhpatha speakers engage in short visits to Darwin, a much smaller number reside long-term in the city. This introduces a different range of linguistic exchange practices, and also establishes some of the social settings encountered by shortterm visitors.

There are a number of established households in Darwin where Murrinhpatha is in frequent use or is the main language of the household. Some of these households are in 'town camps', which are small neighbourhoods set aside for Aboriginal housing.

\footnotetext{
${ }^{5}$ I believe that the term bobo 'goodbye' is associated with Kunwinjku and Kriol, though it may also be used in some Yolyu dialects, for example spelt as bubu in the Ritharrnu dialect.
} 
Others are in mainstream northern Darwin suburbs such as Jingili, Malak and Karama, ${ }^{6}$ or in the satellite city of Palmerston. The town camps, being almost 100\% Aboriginal, are more intensive sites of multilingual exchange, but some suburbs such as Malak also have enough residents and visitors from the Aboriginal homelands to foment frequent multilingual encounters. I have visited seven Murrinhpatha households in Darwin, each of which is organised around either a Murrinhpatha-speaking woman, or jointly managed by a Murrinhpatha-speaking woman together with a non-Indigenous partner. This distinctive gendering of homelands/urban mobility echoes patterns observed elsewhere (Coulehan \& Gaykamanu 2013; Burke 2018)

Between 2018-2020 I was on friendly terms with one particular Murrinhpathaspeaking household in a town camp, having previously got to know one of the residents when he was visiting Wadeye. The house has about 10 long-term residents, though there are usually several short-term visitors from Wadeye staying at the house. The household is centered around an elderly married couple: a Murrinhpatha woman 'Pirrimpe' and her Wadjiginy husband 'Malh'. They met in Wadeye some decades ago when Malh was visiting relatives there. The main language of the household is Murrinhpatha, though Malh also uses some Wadjiginy language in addressing his family, and one of his sons confirmed for me that he understands Wadjiginy, mentioning terms such as pirdup 'tobacco', ngilatj 'lighter' and mang 'money'. Kriol and other Aboriginal languages may also be heard in the household, depending on visitors.

The town camp in which this household is situated has 13 occupied houses, each with a different linguistic repertoire. Table 2 lists the languages reportedly used in each house (a mixture of self-reporting and reports by neighbours), with houses arranged in the table to approximate their arrangement in the camp area (top is south, right column is west). Most of the houses are reported to use more than one Aboriginal language, usually traditional languages, but in one case Kriol. Some households are quite separate, i.e. not relating to each other as kin, but several of the households do have kin relationships, and this generally aligns with the shared languages. For example, Pirrimpe's house 9 stands next to house 5, which is headed by Malh's sister and her MalakMalak husband. Malh reports that he speaks Wadjiginy with this neighbouring household. While this may be the case, I also observed interaction between these households using Murrinhpatha, which reflects the fact that Murrinhpatha is a vibrant language with a large number of fluent speakers, while Wadjiginy has very few speakers.

Table 2. Reported language use at the thirteen houses in a Darwin town camp. For each house, languages are listed in the order in which they were mentioned to me. The house marked 'English' is occupied by a solitary Anglo-Australian man.

1. MalakMalak

2. MalakMalak, Warray

3. Warray, Gun-nartpa

\footnotetext{
6 'Karama' is in fact an alternative name for the Murrinhpatha language, though not one that is used by Murrinhpatha speakers or their immediately neighbouring groups. It is more often rendered as 'Garama', but in any case may have now fallen completely out of usage. Murrinhpatha speakers in Darwin did not seem to be aware that this suburb is named after their language.
} 


\begin{tabular}{ll}
\hline 4. Warray, MalakMalak & \\
5. Wadjiginy, MalakMalak & 9. Murrinhpatha, Wadiginy \\
6. Burarra, Warray & 10. Wadiginy, Warray \\
7. unknown & 11. Burarra \\
8. Kriol & 12. English \\
& 13. Burarra, Kunwinjku \\
\hline
\end{tabular}

The Murrinhpatha-Wadjiginy marriage at the centre of the house 9 is part of a spreading network of marriage connections among Aboriginal people of northern Australia (cf. Gale 1970; Brandl \& Walsh 1983). The Murrinhpatha-Wadjiginy connection is perhaps within the geographic range of traditional exogamous marriage (see map in Figure 2) (Falkenberg \& Falkenberg 1981), but there are many connections in this network that span far greater distances. This is also exemplified in house 9. Pirrimpe and Malh raised five children at the town camp, and two of their sons met wives there. Their wives were not part of already established kin networks, but rather belonged to an 'unkinned' household belonging to a quite separate social networks. Their wives are both Luritja (Western Desert) speakers, who are classificatory sisters. Both couples later moved to live with the wives' relatives, in the towns of Papunya and Kintore on the Luritja homelands. They bore children of their own who were raised on Luritja homelands, though they have also spent time staying at the town camp in Darwin, and staying with relatives of their grandmother in Wadeye. Darwin, Wadeye, Papunya and Kintore constitute the orbit of their upbringing. This orbit has some parallels with Pearson's (2000) vision for Aboriginal futures, though the stations of the cycle are valued more according to kinship connections than economic opportunity. The children's orbit of kin and country is in their multilingual repertoirs, which encompass Murrinhpatha, Luritja and Kriol.

A salient pattern in the kinship network above, and others I documented, is of receptive multilingualism when marriages occur between people who speak different Aboriginal languages. Each of the partners uses their own language to address the other, though Kriol or English are also used when required to facilitate communication. Furthermore, each parent speaks to the children in their own language, and the children learn at least some of each language. This is also reinforced by regular or occasional interaction with other carers, and child peers, who orbit from the homelands. I met other couples in Darwin who report that they practice receptive multilingualism (and in some instances I directly observed this), involving various pairings of Anindilyakwa, Burarra, Kunwinjku, Murrinhpatha, Tiwi, Wadjiginy, Wubuy and Yolngu varieties.

Children born of multilingual marriages are generally at least receptively multilingual, if not active speakers of both parental languages. For example, we saw above that a Murrinhpatha - Anindilyakwa drinking party was centred around a Murrinhpatha speaking man who had married an Anindilyakwa speaking woman. On other occasions I met this man's son, who was brought up orbiting between Anindilyakwa country, Murrinhpatha country, and Darwin. He is quite fluent in both languages, and demonstrated the fact by translating various Murrinhpatha phrases into 
Anindilyakwa. On another occasion, I was working with a combination of Murrinhpatha and Tiwi men in Darwin, and was surprised to hear two of them practicing receptive multilingualism in Murrinhpatha-Tiwi. The Murrinhpatha man explained to me that his mother was Tiwi and his father was Murrinhpatha, and he learnt both their languages when they raised him in Wadeye. This enabled him to perpetuate receptive multilingualism with his Tiwi relatives, or in this case, a Tiwi workmate. It is worth re-emphasising that these language pairings were not part of traditional multilingualism, but rather have emerged in the post-colonisation era.

Homelands Aboriginal people also sometimes learn other Aboriginal languages as adults. At another Darwin town camp, I sat with a Murrinhpatha-speaking man 'Kanardi' and a Kunwinjku man 'Kimukminj' who had married Kanardi's sister. Kimukminj told me he had been hearing Murrinhpatha for the last ten years, and this exposure was primarily in Darwin rather than the Murrinhpatha homelands. He appeared comfortable in understanding Murrinhpatha conversation, and when I asked him if he could speak any, he switched from English to speaking Murrinhpatha himself, using full grammatical sentences. ${ }^{7}$ His brother-in-law Kanardi was raised in Wadeye but had moved to Darwin, where he lived with his Marrithiyel wife 'Muligati'. I have also spent time with Muligati and she is fluent in both Kriol and Murrinhpatha, and sometimes code-switches between the two, for example when speaking with her classificatory sister. These two sisters grew up together, primarily at a Darwin town camp, though they have both also spent time visiting kin in Wadeye. They were raised by some of the same people who feature in Sansom's (1980) town-camp ethnography, and their fluency in Murrinhpatha does not seem altogether consistent with his claim that the use of homelands languages was discouraged at the camp (Sansom 1980: 28).

This adult acquisition of Aboriginal languages is striking, in part because some northern Australian Aboriginal languages, such as Murrinhpatha, are considered by linguists to be highly complex and presumably therefore difficult to learn by adults. However I have not heard homelands Aboriginal people describe these languages as difficult. 'Guyana' a highly multilingual Yolyu man, emphasised the importance of listening when learning a language (I return to his views below). When I asked two Emmi sisters, 'Polo' and 'Ngalhdirri', how Aboriginal people learn each others languages they explained:

AUTHOR: How do you learn?

POLO: Quick way -

NGALHDIRRI: Listening, or they can sing them. Sing the tongue.

'Sing' in Aboriginal English implies a magical process, and also suggests effortlessness on the part of the learner, with the agency instead falling to the owners of the language. In multilingual romances, each person wants their partner to understand their language,

\footnotetext{
${ }^{7}$ This included the use of inflected verbal expressions such as the mam-math 'ear hand.1sG.NFUT-carry = I know it'.
} 
so either they or their kin will use benevolent powers to bestow such an understanding. The new affinal connection is solemnified by a new linguistic exchange.

If a child misses out on learning their father's language, a magical process may be invoked to explain how they learn it later as an adult. As Ngalhdirri went on to explain, one of her classificatory daughters married a Warlpiri man whom she met in Darwin. They had two daughters, who were raised in Darwin, but due to break-up of the marriage, they did not learn Warlpiri growing up. However once they were older, they were sent to the Warlpiri homelands to ensure they were properly immersed in their paternal culture and language:

They sent them back to their father's [homeland], which is Lajamanu, and they didn't know anything about speaking the language. And as they were getting it, they can speak it [Warlpiri].... They sing people. They only turned 18 and they both went back, and a couple of years they come back, they started speaking that language.

Finally, it is worth mentioning that more than one of the multilingual marriages in Nhalhdirri's network grew out of teenagers meeting each other in the 1970s at Kormilda College, a Darwin boarding school that was established for homelands Aboriginal people. This demonstrates how multilingual connections are sometimes mediated by an intercultural institution, largely managed by non-Aboriginal people. The same can be said of various Murrinhpatha-Tiwi connections, which were mediated by the Catholic missionary organisation that managed settlements on both homelands, and at times organised visits of Murrinhpatha people to the Tiwi mission, or vice-versa. Alongside murrinh malarrk 'Arnhem-land language(s)', Tiwi is the only other distant Aboriginal language for which Murrinhpatha people have developed a special name: murrinh nginthanguri, a humorous term which can be translated as 'one-penis language'.

The Darwin-based multilingual network sketched above forms the backdrop for many of the short-term visits described in the previous section. For example, the Murrinhpatha-Wadjiginy household I described above has an almost constant presence of visitors from the Murrinhpatha homelands. This has consequences for both groups. On the one side, it means that long-term Darwin residents have constantly renewed contact with their homeland languages. On the other side, it means that short-term visitors to Darwin socialise with highly mulitingual Darwin networks, which can lead to new multilingual marriage connections and thus further expand the network. In this way, Aboriginal mobility between homelands and Darwin provides its own means for renewing and expanding the multilingual Aboriginal network of northern Australia.

\footnotetext{
${ }^{8}$ There is undoubtedly an interesting story behind this term, but I am yet to learn it.
} 


\section{Recontextualising and rescaling Aboriginal multilingualism}

As we have seen above, homelands Aboriginal people in Darwin engage in distinctive patterns of language use, where Aboriginal languages are interactional tools that build one's social network and social capital, often in ways that go beyond traditional kin/language connections (Brandl \& Walsh 1983). This network is developing against an urban backdrop in which non-Aboriginal social structures dominate, and the English language is an assumed norm of communication. Aspects of Aboriginal linguistic exchange are practiced both in spite of this context and because of this context.

We know that Murrinhpatha speakers have traditionally been multilingual, and documentation of small-scale multilingualism in other homelands regions of northern Australia, especially at Maningrida (Elwell 1982) and Warruwi (Singer and Harris 2016), suggests that there are substantial continuities between contemporary Darwin practice and traditional homelands practices. In particular, receptive multilingualism and the egalitarian valuation of multiple hereditary traditions together favour the maintenance of multiple languages. Languages play an important role in social exchange and networkbuilding, much as they have for thousands of years.

There are other ways in which Murrinhpatha experiences of Darwin reproduce traditional ways of being. We saw, for example, that traditional food collection and grass-burning are sometimes practiced by long-grassers. One man described to me how Murrinhpatha people habitually camp in one particular patch of bushland near Darwin airport. He said, pirranganpe parnam 'they look after it (the bushland)', reflecting a distinctive traditional concept of people nurturing country which in turn nurtures them. But while Murrinhpatha people may look after bushland in Darwin, my consultant also noted that the patch of bush in question is particularly valued because it features a power socket accessible on the external wall of a nearby warehouse. This solves the major problem of how Murrinhpatha long-grassers can recharge their phones. This illustrates how continuity of traditions does not imply unchangingness, or radical cultural separation (Merlan 2005).

The language connections made in Darwin recontextualise Aboriginal multilingualism to much greater geographic distances than would have been typical in pre-colonial times (see map in Figure 2). Darwin acts as a central geographic node for the entire region, fomenting new connections between geographically distant groups. More specifically, such encounters occur at Casuarina shopping centre, at drinking parties in the parks, in town camps, and at educational institutions such as Kormilda College.

But the rescaling of multilingualism to a larger geographic area may also modify the type of language learning that occurs. The geographically dispersed networks described in this article are likely to involve weaker ties (i.e. one's social connections being less likely to be connected to one another), compared to the predominance of strong ties in more traditonal regional networks (Granovetter 1983). Burke (2018) describes the development of weak ties by Warlpiri people in the cities of Adelaide and Alice Springs. Similarly, a Murrinhpatha speaker in Darwin may only have contact with 
a single Anindilyakwa-speaking kin, compared to the traditional regional setting where they would likely be connected to many Marri Ngarr-speaking kin, who were all mutually connected. Such weak ties may produce more partial language exposure, and perhaps restrict the amount of language that can be learnt - for example, only being able to say 'tobacco', 'lighter' and 'where to?' in Anindilyakwa, as compared to having a working vocabulary of a few dozen expressions for Marri Ngarr. However this conjecture requires further research.

Finally, it is worth highlighting that Darwin multilingualism may offer positive signs for the vitality of Aboriginal languages, but this is only true of the languages that are vibrant on homelands communities. Among the Murrinhpatha speakers mentioned in this study, about half actually have other Daly region languages as their patrilects, though they do not regularly use these languages. What is interesting is that they are able to adopt Murrinhpatha as a medium of sociolinguistic exchange: although it may not be their patrilect, they still have strong social connections to this language. Murrinhpatha is part of their identity having grown up at Wadeye on the Murrinhpatha homelands.

\section{Conclusion}

In this article I have described new multilingual practices that have emerged among homelands Aboriginal people in Darwin, the region's only major city. This is the first study that has focused specifically on the use of homelands Aboriginal languages in an urban environment. I have shown that when Aboriginal people from different homelands encounter one another in Darwin, they use their homelands languages to varying extents, with Kriol and English used as 'fallback' languages to mitigate gaps in understanding. I argue that the use of homelands languages in these situations, rather than simply converging on Kriol, is motivated by the social capital associated with these languages. Aboriginal languages represent connections to kin and country. I use the term 'linguistic exchange' to characterise Darwin multilingual encounters in which speakers use homelands languages to index their own kinship networks, and also use elements of their interlocutors' languages to demonstrate respect for the interlocutor's social position. For temporary visitors to Darwin, linguistic exchange thus tends to involve learning a few words in another Aboriginal language. But some homelands people also settle permanently in Darwin, in some cases having married a spouse from a different language group. In these cases more extensive multilingualism may be practiced, demonstrating adult second-language learning. These practices provide positive signs for the future of Aboriginal language use in this region, though it appears that only some languages will be supported by multilingual exchange. 


\section{References}

Angelo, Denise. 2022. Contact language case studies from Australia's shifting langscapes. In Bowern, Claire (ed.), The Oxford handbook of Australian languages. Oxford: Oxford University Press.

Austin-Broos, Diane. 2009. Arrernte present, Arrernte past: Invasion, violence and imagination in Indigenous central Australia. Chicago: University of Chicago Press.

Benn, David. 1994. Community politics in Arnhem Land - Maningrida and Galiwinku (19391978). Darwin: University of the Northern Territory. (Masters thesis.)

Berndt, R.M. \& Berndt, C.H. 1987. End of an era: Aboriginal labour in the Northern Territory. Canberra: AIAS.

Bourdieu, Pierre. 1977. The economics of linguistic exchanges. Social Science Information. SAGE Publications Ltd 16(6). 645-668.

Bourdieu, Pierre. 1991. Language and symbolic power. Cambridge, MA: Harvard University Press.

Brandl, Maria \& Walsh, Michael. 1983. Roots and branches, or the far-flung net of Aboriginal relationships. In Peterson, Nicolas \& Langton, Marcia (eds.), Aborigines, land and land rights, 149-159. Canberra: AIAS.

Brandl, M.M. \& Walsh, Michael. 1982. Speakers of many tongues: toward understanding multilingualism among Aboriginal Australians. International Journal of the Sociology of Language 36. 71-81.

Brown, Penelope \& Levinson, Stephen C. 1987. Politeness: Some universals in language usage. Cambridge: Cambridge University Press.

Burke, Paul. 2018. An Australian Indigenous diaspora: Warlpiri matriarchs and the refashioning of tradition. New York: Berghahn.

Carson, Dean \& Carson, Doris \& Taylor, Andrew. 2013. Indigneous long grassers: Itinerants or problem tourists? Annals of Tourism Research 42. 1-21.

Collman, J. 1988. Fringe-dwellers and Welfare: The Aboriginal Response to Bureaucracy. Brisbane: University of Queensland Press.

Coulehan, Kerin Maureen. 1995. Sitting down in Darwin: Yolyu women from northeast Arnhem Land and family life in the city. Darwin: Northern Territory University. ( $\mathrm{PhD}$ thesis.)

Coulehan, Kerin Maureen \& Gaykamanu, Waymamba. 2013. Family matters: Yolyu women and children and rural-urban mobility. In Hansen, Christine \& Butler, Kathleen (eds.), Exploring urban identities and histories, 51-71. Canberra: AIATSIS.

Day, William Bartlett. 2001. Aboriginal fringe dwellers in Darwin, Australia: Cultural persistence of a culture of resistance? Perth: University of Western Australia. (PhD thesis.)

Day, William Bartlett. 2006. The freedom to sleep: A history from the long grass in Darwin, Northern Territory. Parity 19(10). 14-16.

Di Carlo, Pierpaolo. 2018. Towards an understanding of African endogenous multilingualism: ethnography, language ideologies, and the supernatural. International Journal of the Sociology of Language. De Gruyter Mouton 2018(254). 139-163. (doi:10.1515/ijsl-2018-0037)

Elwell, Vanessa M.R. 1982. Some social factors affecting multilingualism among Aboriginal Australians: a case study of Maningrida. International Journal of the Sociology of Language 36. 83-103.

Evans, Nicholas. 2007. Warramurrungunji undone: Australian languages in the 51st millennium. In Brenzinger, Matthias (ed.), Language Diversity Endangered, 342373. Berlin: Mouton de Gruyter. 
Evans, Nicholas. 2018. The dynamics of language diversity. In Mesthrie, Rajend \& Bradley, David (eds.), The dynamics of language: Plenary and focus lectures from the 20th International Congress of Linguists, 12-41. Cape Town: Univeristy of Cape Town.

Falkenberg, Aslaug \& Falkenberg, Johannes. 1981. The affinal relationship system: A new approach to kinship and marriage among the Australian Aborigines at Port Keats. Oslo: Universitetsforlaget.

Falkenberg, Johannes. 1962. Kin and totem: Group relations of Aborigines in the Port Keats district. Oslo: Oslo University Press.

Fisher, Daniel. 2012. Running amok or just sleeping rough? Long-grass camping and the politics of care in northern Australia. American Ethnologist 39(1). 171-186.

Fisher, Daniel. 2013. Becoming the state in northern Australia: Urbanisation, intraIndigenous relatedness, and the state effect. Oceania 83(3). 238-258.

Gale, Fay. 1970. The impact of urbanization on Aboriginal marriage patterns. Australian Aboriginal anthropology: Modern studies in the social anthropology of the Australian Aborigines, 305-325. Canberra: Australian Institute of Aboriginal Studies.

Giles, Howard \& Ogay, Tania. 2007. Communication accommodation theory. In Whaley, B.B. \& Samter, W. (eds.), Explaining communication: Contemporary theories and exemplars, 293-310. Mahwah, NJ, US: Lawrence Erlbaum Associates Publishers.

Glaskin, Katie. 2012. Anatomies of relatedness: Considering personhood in Aboriginal Australia. American Anthropologist 114(2). 297-308.

Granovetter, Mark. 1983. The strength of weak ties: A network theory revisited. Sociological Theory 1. 201-233.

Green, Jennifer. 2022. Australian Indigenous sign languages. In Bowern, Claire (ed.), The Oxford guide to Australian languages. Oxford: Oxford University Press.

Holmes, Catherine. 2007. Between the long grass and the housed: A qualitative inquiry into the experience of homelessness in Darwin. Sydney: University of Western Sydney. ( $\mathrm{PhD}$ thesis.)

Holmes, Catherine \& McRae-Williams, Eva. 2008. Being undesirable: Law, health and life in Darwin's long grass. Hobart: National Drug Law Enforcement Research Fund.

Irvine, Judith T. 1989. When talk isn't cheap: Language and political economy. American Ethnologist 16(2). 248-267.

Kowal, Emma. 2015. Trapped in the gap: Doing good in Indigenous Australia. New York: Berghahn.

Laycock, Don. 1979. Multilingualism: Linguistic boundaries and unsolved problems in Papua New Guinea. In Wurm, Stephen (ed.), New guinea and neighboring areas: $A$ sociolinguistic laboratory, 81-99. De Gruyter Mouton.

Lüpke, Friederike. 2016. Uncovering small-scale multilingualism. Critical Multilingualism Studies 4(2). 35-74.

Mansfield, John Basil. 2014. Polysynthetic sociolinguistics: The language and culture of Murrinh Patha youth. Canberra: Australian National University. (PhD thesis.)

Mansfield, John Basil. 2022. Sociolinguistic variation. In Bowern, Claire (ed.), The Oxford guide to Australian languages. Oxford: Oxford University Press.

Maypilama, Lawurrpa \& Garngulkpuy, A. \& Christie, Michael \& Greatorex, John \& Grace, Jocelyn. 2004. Yolyu longgrassers on Larrakia land. Darwin: Co-operative Research Centre for Aboriginal and Tropical Health. 
Merlan, Francesca. 1991. Women, productive roles, and monetisation of the 'service mode' in Aboriginal Australia: Perspectives from Katherine, Northern Territory. The Australian Journal of Anthropology 2(3). 259-292.

Merlan, Francisca. 1998. Caging the rainbow: Places, politics, and Aborigines in a north Australian town. Honolulu: University of Hawaii Press.

Merlan, Francisca. 2005. Explorations towards intercultural accounts of socio-cultural reproduction and change. Oceania 75(3). 167-182.

Myers, F.R. 1986. Pintupi country, Pintupi self: Sentiment, place and politics among Western Desert Aborigines. Canberra: Australian Institute of Aboriginal Studies.

Myers, Fred. 1979. Emotions and self: A theory of personhood and political order among Pintupi Aborigines. Ethos 7(4). 343-370.

Neale, Timothy. 2019. Mysterious Motions: A genealogy of 'orbiting' in Australian Indigenous affairs. In Stead, Victoria \& Altman, John (eds.), Labour Lines and Colonial Power (Indigenous and Pacific Islander Labour Mobility in Australia), 259-278. ANU Press.

Pearson, Noel. 2000. Our right to take responsibility. Goanna Print.

Peterson, Nicolas. 1993. Demand sharing: Reciprocity and the pressure for generosity among foragers. American Anthropologist (New Series) 95(4). 860-874.

Peterson, Nicolas. 2013. On the persistence of sharing: Personhood, asymmetrical reciprocity, and demand sharing in the Indigenous Australian domestic moral economy. The Australian Journal of Anthropology 24. 166-176.

Povinelli, Elizabeth. 1994. Labor's lot: The power, history and culture of Aboriginal action. Chicago: University of Chicago Press.

Powell, Alan. 1982. Far country: A short history of the Northern Territory. Carlton: Melbourne University Press.

Pye, Br John MSC. 1972. The Port Keats story. Darwin: Colemans.

Rodríguez Louro, Celeste \& Collard, Glenys. 2021. Working together: Sociolinguistic research in urban Aboriginal Australia. Journal of Sociolinguistics n/a(n/a).

Sansom, Basil. 1980. The camp at wallaby cross: Aboriginal fringe dwellers in Darwin. Canberra: Australian Institute of Aboriginal Studies.

Sansom, Basil. 1988. A grammar of exchange. In Keen, Ian (ed.), Being Black: Aboriginal Cultures in "Settled" Australia, 159-178. Canberra: Australian Institute of Aboriginal Studies.

Singer, Ruth \& Harris, Salome. 2016. What practices and ideologies support small-scale multilingualism? A case study of Warruwi Community, northern Australia. International Journal of the Sociology of Language 2016(241). 163-208.

Sutton, Peter. 1978. Wik: Aboriginal society, territory and language at Cape Keerweer, Cape York Peninsula, Australia. St Lucia: University of Queensland. (PhD thesis.)

Vaughan, Jill. 2021. Enduring and Contemporary Code-Switching Practices in Northern Australia. Languages 6(2). 90.

Ward, Sr. Theresa. 1983. The peoples and their land around Wadeye: Murrinh kanhi ka kardu $i$ da putek pigunu. Wadeye: Wadeye Press.

Wells, Samantha. 2000. Labour, control and protection: The Kahlin Aboriginal Compound, Darwin, 1911-38. In Read, Peter (ed.), Settlement: A history of Australian Indigenous housing, 64-74. Canberra: Aboriginal Studies Press.

Wilkins, David P. \& Nash, David. 2008. The European 'discovery' of a multilingual Australia: The linguistic and ethnographic successes of a failed expedition. In McGregor, William (ed.), Encountering Aboriginal languages: Studies in the history of Australian linguistics, 485-507. Canberra: Pacific Linguistics. 
Wray, Alison \& Grace, George W. 2007. The consequences of talking to strangers: Evolutionary corollaries of socio-cultural influences on linguistic form. Lingua (The Evolution of Language) 117(3). 543-578. 